\title{
Późnoglacjalny rozwój osuwisk w polskich Karpatach zewnętrznych
}

\author{
Antoni Wójcik ${ }^{1}$
}

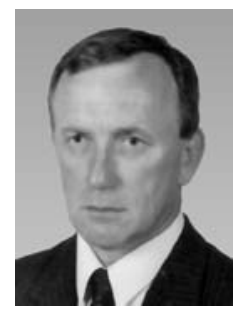

The Late Glacial evolution of landslides in the Polish Outer Carpathian Mountains. Prz. Geol., 67: 397-404; doi: $10.7306 / 2019.34$

A b s tr a c t. The area of Poland, including the Carpathian Mountains, is located in a zone where landslides cause large material damage. This issue can be considered using different time scales. Using various dating methods, it was possible to distinguish periods of increased landslide activity. Among others, the radiometric methods are the most common. Based on the ${ }^{14} C$ dated landslides in Szczawnica-Biaty Stream, Zapadle near Szymbark, Rychwatd near Żywiec and on data published by Margielewski (2006), it was possible to hypothesize that landslides in the Carpathians have been developing over 13,000 years, i.e. since the Oldest Dryas. This is related to the beginning of degradation of the permafrost, which can be considered as the inception of the development of large rock landslides. On the basis of the presented data, it can also be stated that these landslides have been active up to modern times and their development is very long. An example of this is the landslide in Zapadle. The position of the landslide tongue, which is subjected to erosion, is of great importance, which promotes its further activity. Permanent removing of the colluvial material by a stream and its supplementing by subsequent new displacements from the scarp causes that the landslides can be active for a very long period of time.

Keywords: mass movements, Flysch Carpathians, landslide, radiocarbon dating, Late Glacial

Osuwanie jest jednym z najgroźniejszych procesów rozwijających się na polskich stokach. W Karpatach procesy osuwiskowe powodują duże szkody materialne. Zagadnienie to można rozpatrywać $\mathrm{z}$ użyciem różnych skal czasowych. Procesy osuwiskowe zachodzą w Karpatach współcześnie (Rączkowski, Mrozek, 2002; Poprawa, Rączkowski, 2003; Wojciechowski i in., 2012), ale ich początkowy rozwój może sięgać środkowego vistulianu (Sobolewska i in., 1964) lub nawet środkowego plejstocenu (Szczygieł i in., 2019). W przeszłości procesy osuwiskowe zachodziły $\mathrm{w}$ różnym czasie $\mathrm{i}$ miały różne natężenie. Powiązanie tych zdarzeń z występowaniem innych zjawisk daje możliwość wyróżnienia okresów wzmożonej aktywności osuwiskowej (Margielewski, 2006).

Wiek osuwisk na terenie Karpat określa się metodami izotopowymi (Pánek i in., 2015): radiowęglową (Pazdur i in., 1999; Margielewski, 2006), uranowo-torową (Urban $\mathrm{i}$ in., 2015; Szczygieł i in., 2019) oraz nuklidów kosmogenicznych (Pánek i in., 2014, 2017), jak również na podstawie badań palinologicznych (Środoń, 1952; Pawlikowa, 1965), malakofaunistycznych (np. Alexandrowicz, 1996b), a także oznaczeń dendrochronologicznych (Krapiec, Margielewski, 2000; Krąpiec i in., 2008; Šilhán i in., 2012).

Na terenie Beskidu Makowskiego i Wyspowego najwięcej oznaczeń wieku osuwisk dokonano metodą radiowęglową ${ }^{14} \mathrm{C}$ (Margielewski, 2006; Margielewski i in., 2003). Pojedyncze datowania osuwisk przeprowadzono na terenie grzbietu Lasku (Wójcik, 1997), w okolicach Szymbarku (Gil i in., 1974; Wójcik i in., 2006), Beskidu Niskiego (Szczepanek, 2001), Bieszczad (Haczewski, Kukulak, 2004), Pienin i Beskidu Sądeckiego (Alexandrowicz, 1990, 1993,1996a, b).

Datowaniu metodą radiowęglową poddano osady organiczne, głównie torfy, wypełniające bezodpływowe zagłębienia na powierzchni kilku osuwisk w Beskidzie Makowskim i Wyspowym (ryc. 1), które szczegółowo badał Margielewski (2006). Stwierdzono, że np. sedymen- tacja w zagłębieniu w osuwisku pod Kotoniem (Beskid Średni), rozpoczęła się co najmniej $12140 \pm 70$ lat BP (Margielewski, 2001a). Na osuwisku Hajduki sedymentacja osadów organicznych rozpoczęła się jeszcze wcześniej, tj. $13900 \pm 90$ lat BP (Margielewski, Zernitskaya, 2003), a na osuwisku Klakowo $13150 \pm 190$ lat BP (Margielewski, 2001b). Na podstawie wyników tych badań wyróżniono kilka faz rozwoju osuwisk w późnym glacjale i holocenie (Alexandrowicz, 1996b; Margielewski, 2006).

Najbardziej interesujące są osuwiska, których jęzory wkraczają na starsze osady zawierające szczątki organiczne przydatne do określenia wieku nasuwania się jęzora. Przy czym trzeba mieć na uwadze, że początki aktywności takiego osuwiska moga być jeszcze starsze. Określenie wieku takich osadów organicznych umożliwia dokonanie korelacji czasowych w rozwoju osuwisk. Bardzo interesujące są dane dotyczące najstarszych etapów rozwoju współcześnie obserwowanej aktywności osuwisk. Na przykład wyniki palinologicznych datowań osuwiska na Bryjarce (Pawlikowa, 1965) oraz osuwiska w Dziadowych Kątach, gdzie jęzor osuwiska wkroczył na torf datowany na późny dryas (Środoń, 1952), wskazały, że rozwój tych osuwisk został spowodowany zanikiem wieloletniej zmarzliny.

W czasie wykonywania prac wiertniczych na terenach osuwiskowych w polskich Karpatach zewnętrznych wielokrotnie stwierdzono występowanie osadów organicznych. Wyniki datowań tych osadów metodą ${ }^{14} \mathrm{C}$ wskazują, że początkowy etap rozwoju dużych osuwisk rozpoczął się na tym terenie w późnym glacjale - powstały wówczas osuwiska w okolicach Szczawnicy, Szymbarku (osuw. Zapadle) czy Rychwałdu k. Żywca (ryc. 1). Oznaczenia wieku materii organicznej wykonano w Gliwicach. Metode stosowana w tym laboratorium opisał Pazdur i in. (1999). Wykorzystano również wyniki datowań prowadzonych przez laboratorium w Kijowie, zamieszczone w pracy Margielewskiego (2006).

\footnotetext{
${ }^{1}$ Państwowy Instytut Geologiczny - Państwowy Instytut Badawczy, Oddział Karpacki, ul. Skrzatów 1, 31-560 Kraków; antoni.wojcik@pgi.gov.pl
} 


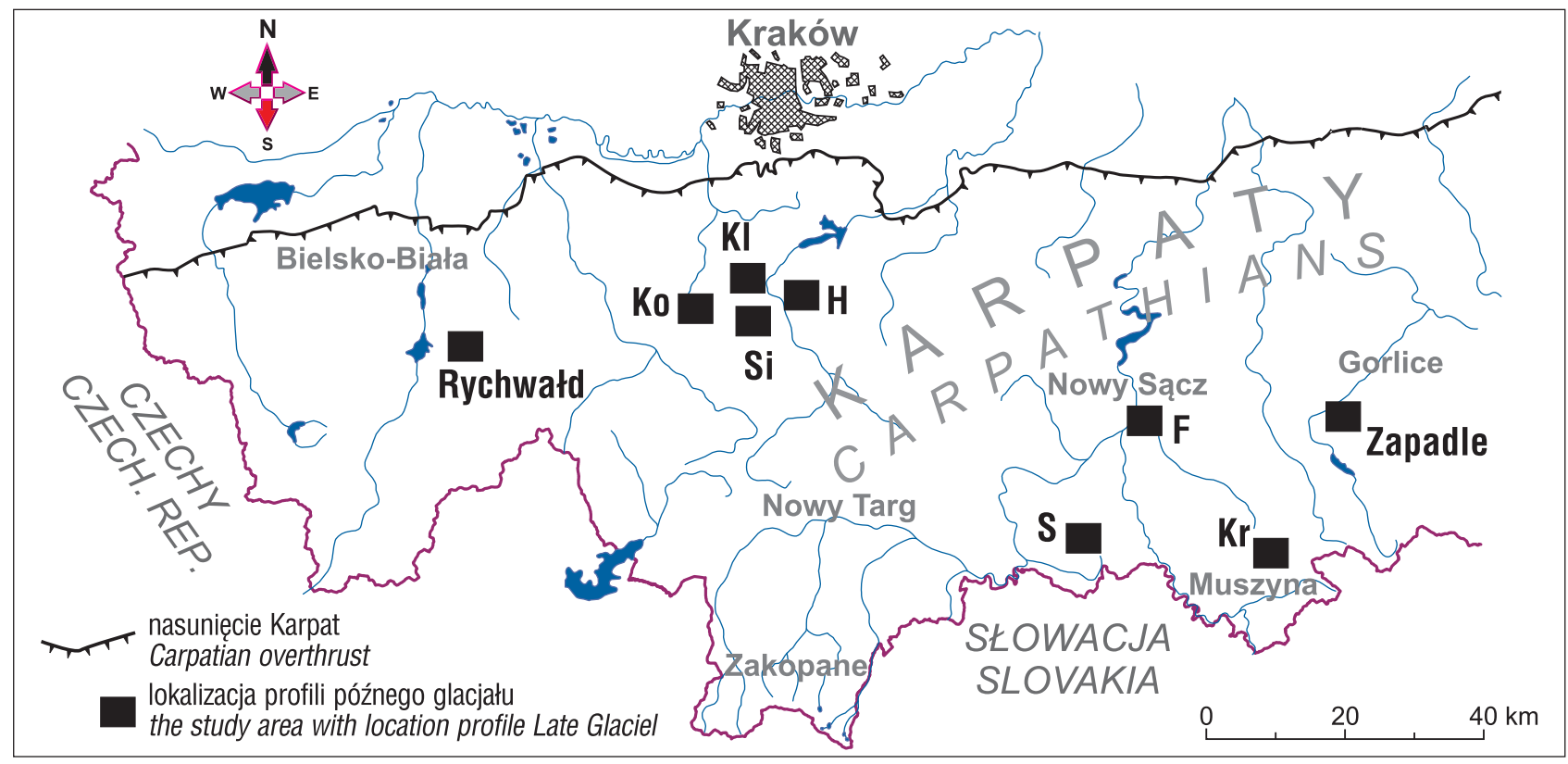

Ryc. 1. Rozmieszczenie wybranych osuwisk w polskich Karpatach zewnętrznych, których inicjacja została wydatowana metodą radiowęglową na późny glacjał: $\mathbf{H}$ - Hajduki; Kl - Klakowo; Ko - Kotoń; Kr - Krynica - Góra Parkowa; S - Szczawnica; Si Siódmowo

Fig. 1. Distribution of landslides in the Polish Outer Carpathians, the initiation of which is dated back to Late Glacial: $\mathbf{H}$ - Hajduki; KI - Klakowo; Ko - Kotoń; Kr - Krynica - Góra Parkowa; S - Szczawnica; Si - Siódmowo

Celem niniejszego artykułu jest ocena stabilności kilku karpackich osuwisk, których rozwój rozpoczął się w późnym glacjale, a ich aktywność jest obserwowana do dziś i wskazanie na ich przykładzie, że zabudowa i infrastruktura na starych osuwiskach mogą być zagrożone.

\section{OSUWISKO W POTOKU BIAŁYM K. SZCZAWNICY}

Okolice Szczawnicy są znane z występowania osadów organicznych na terenach osuwiskowych, m.in. na Bryjarce (Pawlikowa, 1965), w wąwozie Homole i Potoku Ścigockim (Alexandrowicz, 1993, 1996a, b). Na północ od Szczawnicy torfy odkryto w dnie doliny Potoku Białego, będącego dopływem Potoku Skotnickiego.

Dolina Potoku Białego rozcina południowe stoki Dzwonkówki (982,5 m n.p.m.) w Paśmie Radziejowej. Jest to wąska dolina wciosowa. Na zboczach tej doliny po obu stronach występują duże i głębokie, skalne osuwiska strukturalne (Laskowicz, Wójcik, 2014). W prawostronnej części doliny znajduje się zespół osuwiskowy o powierzchni 21,8 ha (ryc. 2), rozpoczynający się w rejonie grzbietu Kuśnierzówka na wysokości 808 m n.p.m. Jęzor o długości ok. $800 \mathrm{~m}$ schodzi do dna doliny na wysokość $589 \mathrm{~m}$ n.p.m. (ryc. 2). Osuwisko rozpoczyna się charakterystycznym zespołem skarp o kolistym przebiegu (ryc. 2). W obrębie tego osuwiska można wyróżnić dwie, wyraźnie zaznaczające się, strefy: południową i północną. Rozpoczynają się one oddzielnymi skarpami głównymi o wysokości do $8 \mathrm{~m}$, wyraźnie zaznaczającymi się w rzeźbie grzbietu. Wyraźne są też skarpy boczne, osiagające do 6-8 $\mathrm{m}$ wysokości, a ich przebieg jest zbliżony do prostolinijnego, co sugeruje tektoniczne założenia osuwiska. W środkowej części osuwiska koluwia łączą się i mają wspólny jęzor osuwiskowy, rozcinany przez Potok Biały. Stok, na którym rozwinęło się osuwisko, ma nachylenie $15^{\circ}$. Osuwisko to rozwinęło się na piaskowcach magurskich w facji muskowitowej, w warstwach z Kowańca i w piaskowcach z Piwnicznej (Golonka, Rączkowski, 1984) i należy do osuwisk, które można określić jako złożone.

Po lewej stronie doliny znajduje się osuwisko skalne (ryc. 2) rozwinięte na wychodniach warstw z Kowańca i w piaskowcach z Piwnicznej (Golonka, Rączkowski, 1984). Rozpoczyna się ono skarpą skalną o wysokości do $9,0 \mathrm{~m}$, na rzędnej $731 \mathrm{~m}$ n.p.m. i ma ok. $415 \mathrm{~m}$ długości oraz $400 \mathrm{~m}$ szerokości (ryc. 2). Poniżej skarpy głównej występuje obniżenie o cechach szerokiego rowu rozpadlinowego $\mathrm{z}$ rozciaggania. $\mathrm{W}$ dolnej części osuwiska zarysowują się wyraźne progi. Czołem schodzi ono na wysokość 560 m n.p.m. $\mathrm{W}$ dnie doliny łączy się z czołem osuwiska rozwiniętego $\mathrm{w}$ prawostronnej części doliny (ryc. 2).

Współcześnie czoła obu osuwisk są rozcinane przez Potok Biały. W przeszłości ich jęzory zablokowały przepływ w korycie i zacisnęły dolinę potoku. W dnie doliny nastąiła wówczas akumulacja osadów rzecznych i organicznych, które zostały rozcięte przez współczesny potok. W skarpie potoku na wysokości 590 m n.p.m. odsłania się następujący profil osadów (ryc. 2):

$\square$ 0,00-0,40 m-torfy zailone barwy ciemnobrunatnej o różnym stopniu rozłożenia;

$\square$ 0,40-0,50 m-iły piaszczyste barwy popielatej;

$\square$ 0,50-0,60 m-torfy barwy ciemnobrunatnej, warstwowane szarymi mułkami;

口 $0,60-0,90 \mathrm{~m}$ - iły barwy popielatej z drobnym rumoszem piaskowcowym.

Z odsłonięcia pobrano dwie próbki do oznaczeń wieku metodą radiowęglową $\left({ }^{14} \mathrm{C}\right)$. Otrzymano następujące wyniki: wiek próbki pobranej z głębokości $0,30-0,40 \mathrm{~m}$ został oceniony na $12210 \pm 85 \mathrm{BP}$ (GdS-508), a wiek próbki z głębokości $0,50-0,60 \mathrm{~m}-$ na $13060 \pm 100 \mathrm{BP}$ (GdS-501), przy czym wiek kalibrowany może mieścić się w przedziale od 15851 do 15088 lat $(95,4 \%)$. Występowa- 


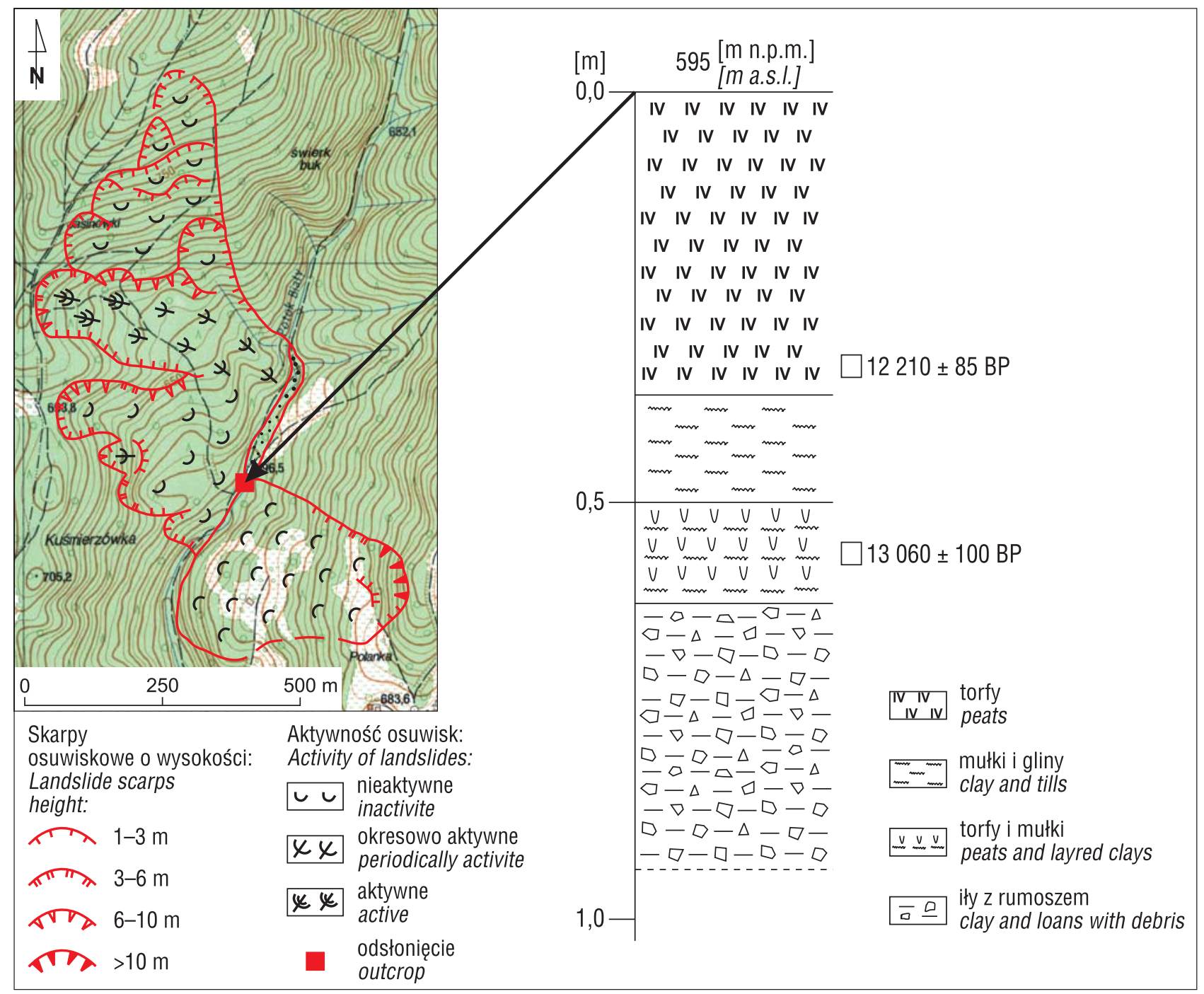

Ryc. 2. Osuwisko w Potoku Białym k. Szczawnicy - lokalizacja oraz profil badanych utworów

Fig. 2. Szczawnica-Potok Biały landslide - localization and profile of the examined deposits

nie tak starych osadów stwierdzono, jak dotąd, jedynie w osuwiskach Hajduki i Klakowo (Margielewski, 2006).

Jak wspomniano, w badanym rejonie na północ od Szczawnicy akumulacja organiczna nastapiła po nasunięciu się koluwiów do doliny Potoku Białego i jego zatamowaniu. Początek akumulacji, według otrzymanych datowań ${ }^{14} \mathrm{C}$, odpowiada najstarszemu dryasowi oraz interstadiałowi bølling. Rozwój dużych osuwisk na tym terenie można powiązać z początkiem degradacji wieloletniej zmarzliny w późnym glacjale. Rozmarzające podłoże oraz znaczne nawodnienie sprzyjało nasileniu ruchów masowych, a zwłaszcza aktywności dużych osuwisk strukturalnych. Późniejsze przemieszczenia grawitacyjne przemodelowały powierzchnię jęzora osuwiskowego. Obecność iłów między dwiema warstwami torfów wskazuje na przerwy w sedymentacji organicznej lub nawet na usunięcie części poprzednio akumulowanych osadów organicznych w czasie wezbrań powodziowych. Pojawienie się mułków wskazuje na zmianę środowiska sedymentacji $z$ organicznej na mineralną. Prawdopodobnie został udrożniony przepływ wód strumienia, który wpłynął na stabilność osuwiska pomiędzy depozycją pierwszej i drugiej warstwy materii organicznej. Stropowa warstwa torfu sugeruje drugą fazę aktywności osuwiska.

\section{OSUWISKO ZAPADLE K. SZYMBARKU}

Osuwisko Zapadle znajduje się na pograniczu Beskidu Niskiego i Dołów Jasielsko-Sanockich (ryc. 1), a administracyjnie jego obszar należy do południowej części wsi Szymbark. Jest to osuwisko subsekwentne o powierzchni 26,2 ha. Rozwinęło się ono na północno-zachodnich stokach grzbietu Bartniej Góry (ryc. 3 i 4). Na wysokości 472,5 m n.p.m. rozpoczyna się ono skarpą główną o wysokości do $6 \mathrm{~m}$, a czołem sięga koryta potoku Bielanka (349,5 m n.p.m.). Skarpa południowa, założona na wychodniach piaskowców magurskich, osiaga do 25 m wysokości. Poniżej, w koluwiach występują bloki piaskowcowe. W korycie potoku osuwisko kontaktuje z czołem osuwiska Hucisko, schodzącego z lewostronnych zboczy doliny (ryc. 3). Osuwisko jest ciagle aktywne i przemieszcza materiał koluwialny do koryta Bielanki, utrudniając jej przepływ. Było ono monitorowane w latach 70. XX w. klasycznymi metodami geodezyjnymi (Gil, Kotarba, 1977, 1979, 1985). Od 2001 r. podlega monitoringowi powierzchniowemu, prowadzonemu z użyciem odbiorników GPS, a w 2009 r. rozpoczęto wgłębny monitoring tej struktury (Nescieruk i in., 2014a). 


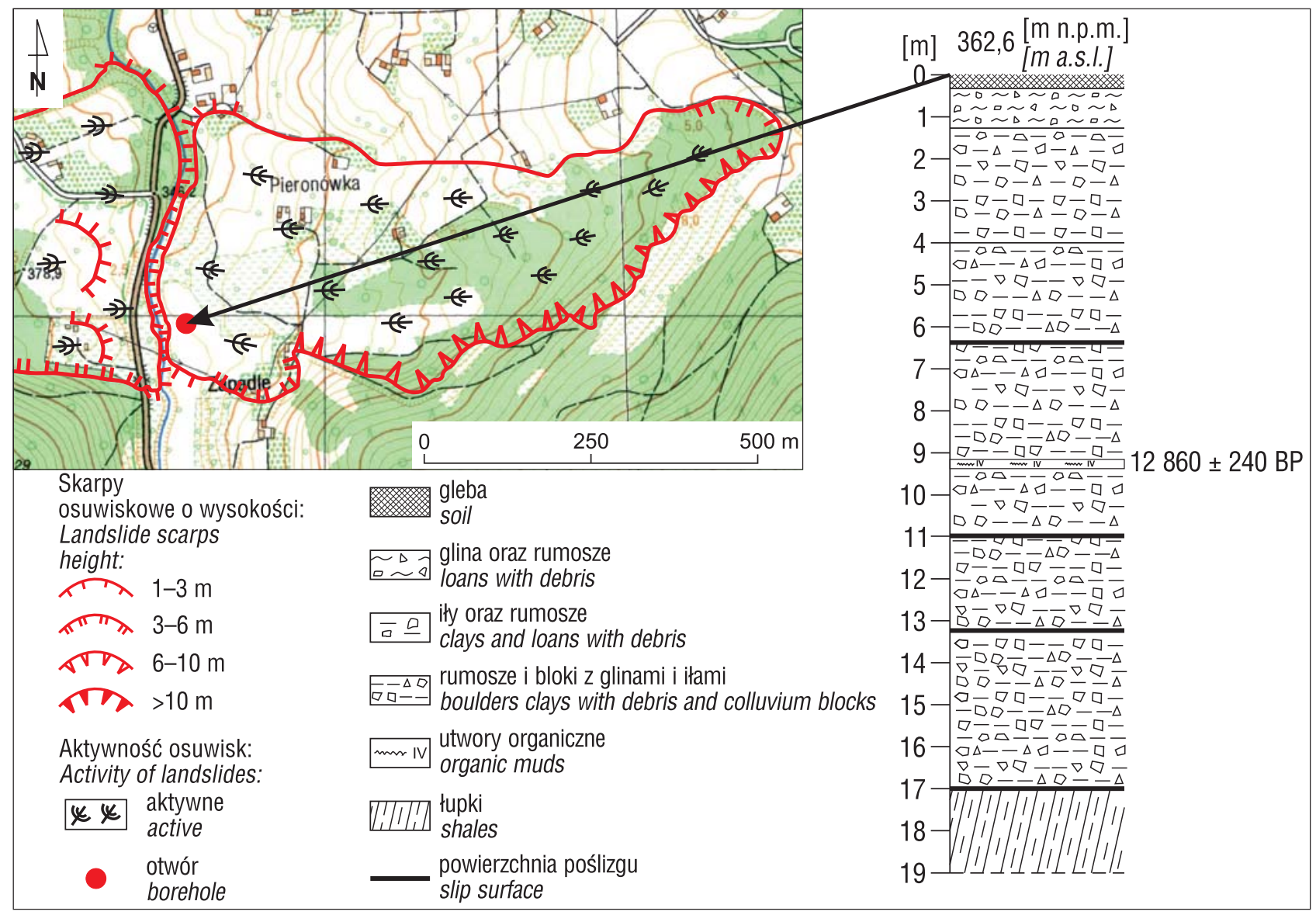

Ryc. 3. Osuwisko Zapadle - lokalizacja oraz profil utworów

Fig. 3. Zapadle landslide - localization and profile of the examined deposits

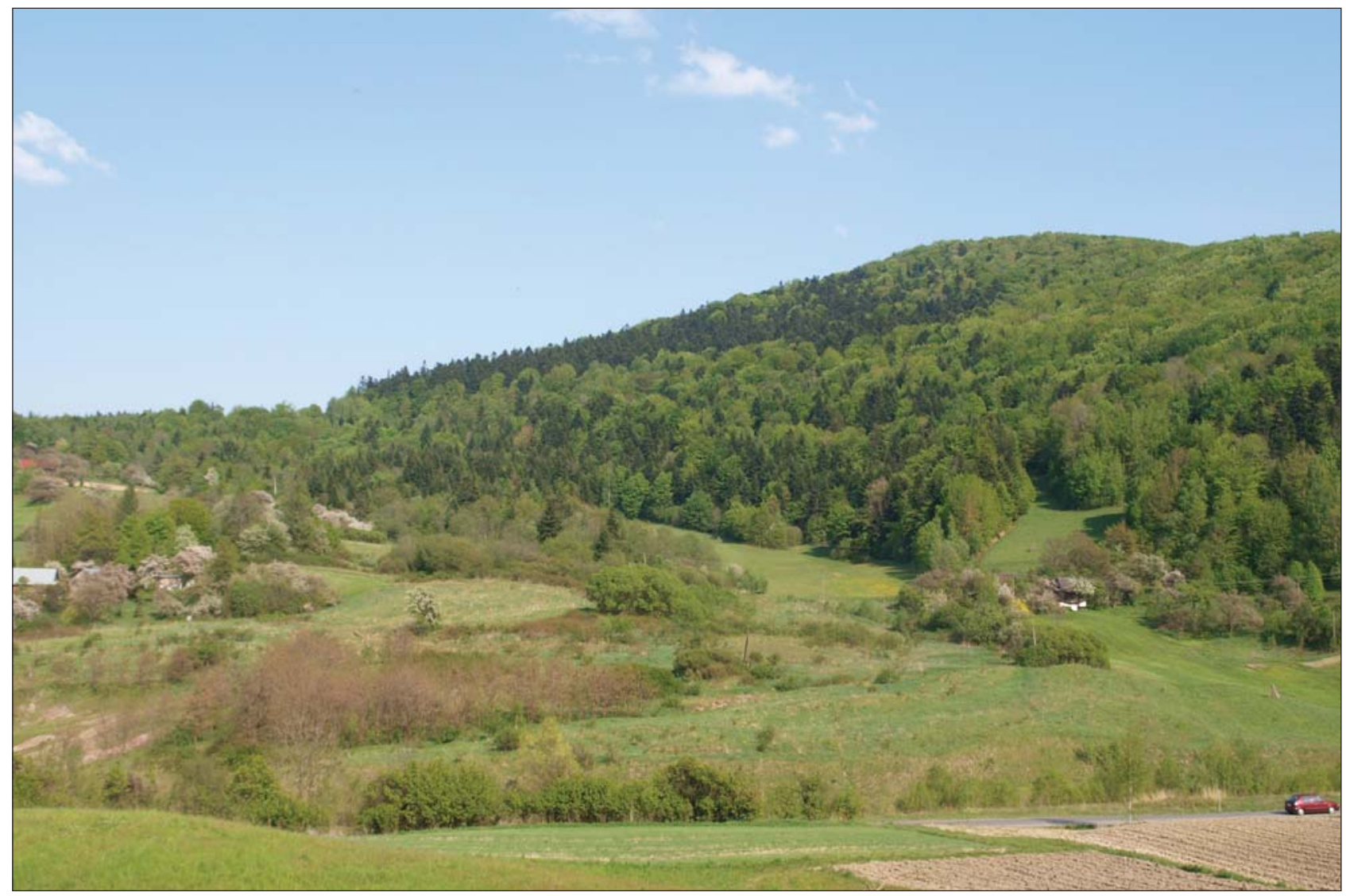

Ryc. 4. Osuwisko Zapadle

Fig. 4. Zapadle landslide 
Osuwisko Zapadle rozwinęło się w strefie występowania łupków pstrych, leżących między wychodniami piaskowców magurskich na południu a warstwami inoceramowymi na północy. Taki układ warstw skalnych spowodował asymetryczny ksztalt form osuwiskowych, m.in. skarp bocznych - wyższych na południu, a niższych na północy. Aktywność osuwiska wykazuje dużą dynamikę przemieszczeń w strefie powierzchniowej, na co wskazuja mikro- i makroformy na jego powierzchni, szczeliny oraz okresowe jeziorka. Teren ten podlegał wielokrotnemu przemodelowaniu, o czym świadczą przekazy miejscowej ludności i zapisy w materiałach archiwalnych. Wcześniej było ono nazywane osuwiskiem pod Dylagiem (Wójcik, 1958). W górnej części odnawiało się w 1918 r. Przemieszczenia są obserwowane co pewien czas, m.in. odnotowano je w latach 1970, 1979, 1990, 2001 i 2006.

Z obserwacji Gila i Kotarby (1977) wynika, że w okresie 3 lat przemieszczenia zastabilizowanych punktów pomiarowych przekraczały w środkowej części tego osuwiska $8,0 \mathrm{~m}$. Aktywność ta jest związana z usuwaniem koluwium przez Bielankę, co skutkuje destabilizacją przez podcinanie i powoduje kolejną aktywację osuwiska.

W ramach prac prowadzonych w celu zamontowania inklinometrów na osuwisku Zapadle wykonano wiercenia. $\mathrm{W}$ jednym $\mathrm{z}$ nich, usytuowanym w dolnej części jęzora (na wysokości 362,6 m n.p.m.), na głębokości 9,4 m nawiercono osady organiczne - muły zawierające drobne fragmenty drewna (gałęzi). Pobrano z nich próbkę materii organicznej, której wiek oceniono na $12860 \pm 240$ BP (Gd 30249; tab. 1). Niżej w profilu tym znajdują się rumosze, lokalnie słabo obtoczone. Do głębokości 13,2 m stwierdzono zazębianie się utworów stokowych z rzecznymi. Prawdopodobnie osuwisko zeszło do dna doliny położonej wówczas na rzędnej 359,4 m n.p.m. i zatamowało potok. Dno doliny zostało zasypane warstwą o miąższości blisko $3,4 \mathrm{~m}$, na której osadziła się $0,1 \mathrm{~m}$ miąższości warstwa mułków ze szczątkami organicznymi. Współczesne koryto potoku występuje w tym miejscu na rzędnej 357,5 m n.p.m., czyli ok. $2 \mathrm{~m}$ niżej niż próbka pobrana z koluwiów do oznaczeń radiometrycznych.

Wynik datowania wskazuje, że osuwisko było już aktywne we wczesnym bølingu, kiedy do dna doliny zsunęły się koluwia. Data ta odpowiada początkowym fazom akumulacji organicznej w zagłębieniach bezodpływowych na ternie osuwisk Hajduki i Klakowo (Margielewski, 2006). Uruchomienie procesów osuwiskowych musiało się wcześniej rozpocząc i mogło przypadać na czas najstarszego dryasu. Największy wpływ na rozwój osuwiska w holocenie miała erozja potoku Bielanka.

\section{RYCHWALD}

W zachodniej części Karpat zewnętrznych, w Paśmie Kiczory-Zwaliska w okolicach Rychwałdu znajduje się osuwisko, które rozwinęło się w utworach płaszczowiny przedmagurskiej (grybowskiej) i magurskiej (Ryłko, Paul, 2014). Powstało ono w strefie kontaktu tektonicznego gruboławicowych piaskowców z Mutnego (warstwy inoceramowe) oraz ilasto-marglistych utworów eocenu (seria grybowska), które dominują w podłożu osuwiska. Jest to jedno $\mathrm{z}$ wielu osuwisk występujących w gminie Gilowice (Wieczorek, 2009). Nisza osuwiskowa od południa jest ograniczona skarpą główną, założoną na wychodniach gru- boławicowych piaskowców w strefie ich nasunięcia na niższy element tektoniczny. Warstwy występujące w podłożu osuwiska są silnie zdeformowane tektonicznie i sfałdowane. Osuwisko w Rychwałdzie jest ograniczone dwudzielna skarpą główną o wysokości do $10 \mathrm{~m}$ (ryc. 5). Poniżej skarpy uformowało się rozległe spłaszczenie - prawdopodobnie w wyniku osunięcia pakietu piaskowców. Powierzchnia koluwiów jest urozmaicona progami akumulacyjnymi oraz nierównościami. Spływ wód atmosferycznych po powierzchni osuwiska jest niezorganizowany, co dodatkowo sprzyja nawadnianiu koluwiów. Osuwisko jest monitorowane, a wyniki prowadzonych prac monitoringowych i robót geologicznych wskazują (Nescieruk i in., 2014b), że jest ono aktywne. Przemieszczenia w otworach inklinometrycznych odnotowano na kilku głębokościach, przy czym maksymalna głębokość współcześnie czynnej powierzchni poślizgu wynosi $22,0 \mathrm{~m}$. Odnotowano także ruch na innych płaszczyznach poślizgu, głównie na głębokości ok. 6 i $10 \mathrm{~m}$ oraz w przedziale 13-19 m p.p.t. (Nescieruk i in., 2014b).

$\mathrm{W}$ górnej części osuwiska w trakcie wiercenia otworu pod inklinometr, stosunkowo płytko, bo na głębokości $2,8 \mathrm{~m}$, pod glinami piaszczystymi nawiercono osady organiczne. Wiek tych osadów określono na $11760 \pm 140$ lat (GdC-250). Prawdopodobnie wypełniają one rów rozpadlinowy.

Rozwój osuwiska rozpoczął się zatem w późnym glacjale, nie później niż 11760 lat temu, czyli przypada na starszy dryas, a samo wypełnienie zagłębienia po rowie rozpadlinowym i akumulacja organiczna nastąiły w allerødzie. Czas rozwoju osuwiska w Rychwałdzie jest zbliżony do dat aktywności osuwiska Siódmowo, otrzymanych przez Margielewskiego (2006).

\section{PODSUMOWANIE}

Badania osuwisk na terenie Karpat dostarczyły danych, które umożliwiły bliższe określenie czasu ich uruchomienia i aktywności. Kompilacja wyników tych badań z danymi uzyskanymi przez Margielewskiego (2006) pozwoliła postawić tezę, że osuwiska na terenie Karpat mają długi czas rozwoju, rozpoczynający się ponad 13 tys. lat temu (tab. 1). Rozwój tych osuwisk może trwać do tej pory, czego najlepszym przykładem jest osuwisko Zapadle, gdzie przemieszczenia nadal są obserwowane (Nescieruk i in., 2014a). Wiek ${ }^{14} \mathrm{C}$ osadów pobranych z osuwiska koło Szczawnicy sięga nawet 15 tys. lat - data ta nawiązuje prawdopodobnie do początków degradacji wieloletniej zmarzliny. Prawdopodobnie są to jedne z najstarszych osuwisk widocznych we współczesnej rzeźbie na terenie Karpat. W holocenie osuwiska te uaktywniały się i zwiększały swoje powierzchnie.

W tabeli 1 zestawiono dostępne wyniki datowań osuwisk w Karpatach zewnętrznych, których uruchomienie można wiązać z późnym glacjałem. Na terenie Karpat są czasami wyróżniane ślady po starszych osuwiskach, lecz ich jednoznaczna identyfikacja na podstawie obserwacji powierzchniowych jest bardzo trudna. Przykładem moga być dane z rejonu Kalackiej Turni w Tatrach, gdzie na podstawie wyników badań jaskini, danych geofizycznych oraz wyników datowań ( $280 \pm 7$ ka i $265 \pm 8 \mathrm{ka}$ ) Szczygieł i in. (2019) przyjęli występowanie ruchów masowych w czasie MIS 9 i MIS 8. Procesy te uaktywniły się jeszcze ok. $35 \pm 4$ ka (Szczygieł i in., 2019), ale ich formy na powierzchni sa słabo zachowane. Pánek i in. (2017) opisali także duże, sta- 


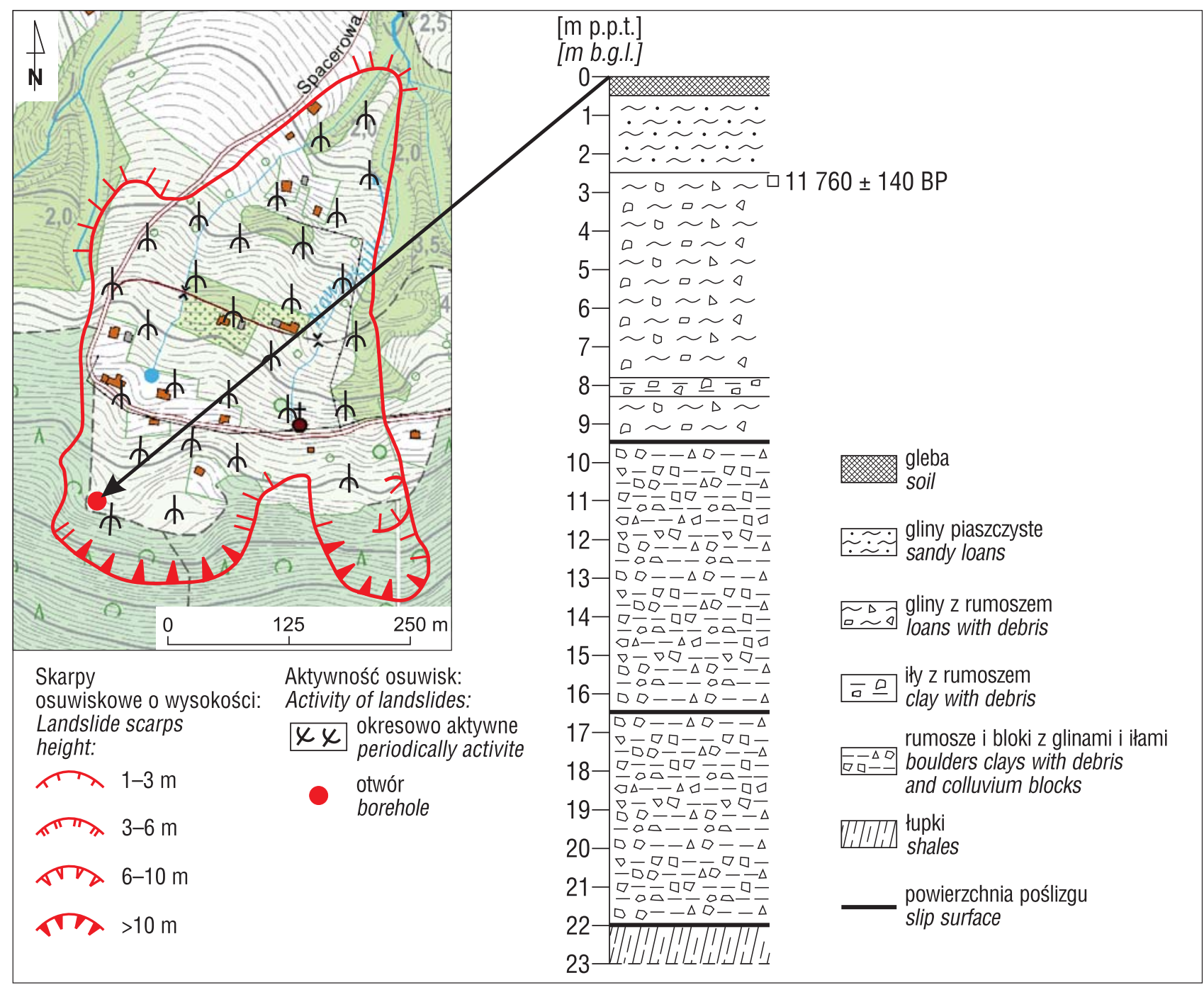

Ryc. 5. Osuwisko w Rychwałdzie - lokalizacja oraz profil utworów

Fig. 5. Rychwałd landslide - localization and profile of the examined deposits

re osuwisko k. Chlebovic, przy czym we współczesnej rzeźbie terenu jest widoczna tylko jego górna część, a części środkowa i dolna zostały uznane za paleoosuwisko. Taka interpretacja wynika z oznaczeń wieku $\left({ }^{14} \mathrm{C}\right)$ części organicznych, mieszczących się w interwale 51-56 ka BP. Co do poprawności interpretacji genezy przykrywających je diamiktytów można mieć wątpliwości, gdyż skały te mogły się osadzić na skutek soliflukcji.

Na podstawie wyników datowań osuwisk metodą ${ }^{14} \mathrm{C}$, przeprowadzonych dotychczas na terenie polskich Karpat zewntęrznych (tab. 1), można stwierdzić, że najstarszą z tych form jest osuwisko Hajduki w Beskidzie Średnim (Margielewski, Zernitskaya, 2003). Uzyskane daty wskazują, że akumulacja materii organicznej na powierzchni osuwiska Hajduki nastapiła w najstarszym dryasie. W najstarszym dryasie rozwijały się także osuwiska w okolicach Szczawnicy i Klakowa (Beskid Makowski; ryc. 1; tab. 1) oraz w innych częściach Karpat. Datowania materii organicznej pobranej z osuwiska Zapadle k. Gorlic, z osuwiska Kotoń (Margielewski, 2001a) czy z osuwiska na Górze Parkowej w Krynicy (Alexandrowicz, 1996b) świadczą o tym, że formy te są nieco młodsze powstały w interfazie bølling (tab. 1). Jeszcze młodsze sa pozostałe badane osuwiska (tab. 1).
Analiza dotychczasowych wyników oznaczeń wieku dużych osuwisk między Żywcem a Gorlicami (tab. 1) prowadzi do wniosku, że współczesne osuwiska na terenie Karpat mają długi cykl rozwojowy, rozpoczynający się pod koniec ostatniego piętra zimnego. Inicjacja tych procesów osuwiskowych była związana z zanikiem wieloletniej zmarzliny w późnym glacjale. Słabnięcie procesów soliflukcji oraz ustępowanie zmarzliny spowodowało rozwój procesów osuwiskowych, przypadający na czas późnego glacjału (Starkel, 1984) - ponad 13000 lat BP. Duży wpływ na aktywność osuwisk miała boczna i wgłębna erozja dolin przez potoki, a zwłaszcza odprowadzanie koluwiów dostarczanych przez procesy osuwiskowe do ich koryt przykładem tego jest osuwisko w Zapadlu.

Wyniki oznaczeń radiometrycznych metodą ${ }^{14} \mathrm{C}$, uzyskane z den zagłębień bezodpływowych oraz z dolnych części jęzorów osuwiskowych, pozwalają wiązać czas rozwoju procesów osuwiskowych z najstarszym dryasem lub interfazą bølling. W tym czasie nastąpił rozwój osuwiska w Potoku Białym k. Szczawnicy. Znacznie więcej osuwisk uruchomiło się w interfazie bølling, należy do nich m.in. osuwisko Zapadle k. Gorlic, które zsunęło się do doliny Bielanki. 
Tab. 1. Osuwiska w polskich Karpatach zewnętrznych - datowane metodą ${ }^{14} \mathrm{C}$ i uznane za starsze od 10000 lat BP Table 1. Landslides of the Polish Outer Carpathians dated via radiocarbon, older than $10000 \mathrm{y}$. BP

\begin{tabular}{|c|c|c|c|c|c|}
\hline $\begin{array}{l}\text { Osuwisko } \\
\text { Landslide }\end{array}$ & $\begin{array}{l}\text { Wiek }{ }^{14} \mathrm{C} \text { BP } \\
\text { Age }{ }^{14} C B P\end{array}$ & $\begin{array}{l}\text { Symbol } \\
\text { Symbol }\end{array}$ & $\begin{array}{c}\text { Chronozony } \\
\text { (Mangerund i in., 1974) } \\
\text { Chronozones } \\
\text { (Mangerund et al., 1974) }\end{array}$ & $\begin{array}{c}\text { Lokalizacja } \\
\text { Location }\end{array}$ & $\begin{array}{l}\text { Bibliografia } \\
\text { Bibliography }\end{array}$ \\
\hline \multirow{4}{*}{ Hajduki } & $13900 \pm 90$ & Ki-10048 & \multirow{4}{*}{$\begin{array}{l}\text { najstarszy dryas-bølling } \\
\text { Oldest Dryas-Bølling }\end{array}$} & \multirow{4}{*}{$\begin{array}{c}\text { Beskid Średni } \\
\text { - zagłębienie w górnej } \\
\text { części osuwiska } \\
\text { Beskid Średni-hollow } \\
\text { (sag-depression) in the } \\
\text { upper part of landslide }\end{array}$} & \multirow{4}{*}{$\begin{array}{c}\text { Margielewski, } \\
\text { Zerniitskaya (2003) }\end{array}$} \\
\hline & $13830 \pm 90$ & Ki-7772 & & & \\
\hline & $10570 \pm 120$ & Ki-9764 & & & \\
\hline & $10220 \pm 80$ & Ki-10047 & & & \\
\hline \multirow[b]{2}{*}{$\begin{array}{l}\text { Potok Biały k. } \\
\text { Szczawnicy }\end{array}$} & $13060 \pm 100$ & GdS-501 & \multirow[b]{2}{*}{$\begin{array}{l}\text { najstarszy dryas-bølling } \\
\text { Oldest Dryas-Bølling }\end{array}$} & \multirow{2}{*}{$\begin{array}{c}\text { Beskid Sądecki } \\
\text { - jęzor osuwiskowy } \\
\text { Beskid Sadecki } \\
\text { - slip tongues }\end{array}$} & \multirow[b]{2}{*}{$\begin{array}{c}\text { Wójcik } \\
\text { - nowe stanowisko } \\
\text { Wójcik-new position }\end{array}$} \\
\hline & $12210 \pm 85$ & GdS 508 & & & \\
\hline Zapadle k. Gorlic & $12860 \pm 240$ & Gd-30249 & $\begin{array}{l}\text { bølling } \\
\text { Bølling }\end{array}$ & $\begin{array}{c}\text { Beskid Niski } \\
\text { - jęzor osuwiskowy } \\
\text { Beskid Niski } \\
\text { - slip tongues }\end{array}$ & $\begin{array}{c}\text { Wójcik } \\
\text { - nowe stanowisko } \\
\text { Wójcik-new position }\end{array}$ \\
\hline \multirow{9}{*}{ Klakowo } & $12300 \pm 150$ & Ki-7955 & \multirow{9}{*}{$\begin{array}{c}\text { najstarszy dryas-najmłodszy dryas } \\
\text { Oldest Dryas-Youngest Dryas }\end{array}$} & \multirow{9}{*}{$\begin{array}{c}\text { Beskid Makowski-- } \\
\text { zagłębienie w górnej } \\
\text { części osuwiska } \\
\text { Beskid Makowski- } \\
\text { hollow (sag-depression) } \\
\text { in the upper part } \\
\text { of landslide }\end{array}$} & \multirow{9}{*}{ Margielewski (2001) } \\
\hline & $13150 \pm 190$ & Ki-8857 & & & \\
\hline & $12100 \pm 50$ & Ki-7960 & & & \\
\hline & $11290 \pm 250$ & Ki-7956 & & & \\
\hline & $11410 \pm 200$ & Ki-7953 & & & \\
\hline & $11770 \pm 200$ & Ki-7954 & & & \\
\hline & $11800 \pm 140$ & $\mathrm{Ki}-7957$ & & & \\
\hline & $11100 \pm 170$ & Ki-7958 & & & \\
\hline & $10500 \pm 150$ & Ki-7959 & & & \\
\hline \multirow{5}{*}{ Kotoń } & $12140 \pm 70$ & Ki-7905 & \multirow{5}{*}{$\begin{array}{l}\text { bølling-młodszy dryas } \\
\text { Bølling-Younger Dryas }\end{array}$} & \multirow{5}{*}{$\begin{array}{c}\text { Beskid Makowski - } \\
\text { zagłębienie w górnej } \\
\text { części osuwiska } \\
\text { Beskid Makowski - } \\
\text { hollow (sag-depression) } \\
\text { in the upper part } \\
\text { of landslide }\end{array}$} & \multirow{5}{*}{ Margielewski i in. (2003) } \\
\hline & $11940 \pm 70$ & Ki-7781 & & & \\
\hline & $11770 \pm 80$ & $\mathrm{Ki}-7782$ & & & \\
\hline & $11540 \pm 100$ & Ki-7968 & & & \\
\hline & $11150 \pm 100$ & $\mathrm{Ki}-7967$ & & & \\
\hline Rychwałd & $11760 \pm 140$ & GdC-250 & $\begin{array}{l}\text { allerød } \\
\text { Allerød }\end{array}$ & $\begin{array}{c}\text { Grzbiet } \\
\text { Kiczory-Zwalisk } \\
\text { - górna część osuwiska } \\
\text { Beskid Sadecki Ridge - } \\
\text { in the upper part } \\
\text { of landslide }\end{array}$ & $\begin{array}{c}\text { Wójcik } \\
\text { - nowe stanowisko } \\
\text { Wójcik - new position }\end{array}$ \\
\hline Osieczka & $10290 \pm 200$ & Ki-11844 & $\begin{array}{l}\text { młodszy dryas } \\
\text { Younger Dryas }\end{array}$ & $\begin{array}{c}\text { Beskid Makowski - } \\
\text { zagłębienie w górnej } \\
\text { części osuwiska } \\
\text { Beskid Makowski- } \\
\text { hollow (sag-depression) } \\
\text { in the upper part } \\
\text { of landslide }\end{array}$ & Margielewski (2006) \\
\hline \multirow{3}{*}{ Siódmowo } & $11530 \pm 90$ & Ki-11137 & \multirow{3}{*}{$\begin{array}{l}\text { starszy dryas-allerød } \\
\text { Older Dryas-Allerød }\end{array}$} & \multirow{3}{*}{\begin{tabular}{|} 
Beskid Makowski \\
- górna część osuwiska \\
Beskid Makowski-the \\
upper part of landslide
\end{tabular}} & \multirow{3}{*}{ Margielewski (2006) } \\
\hline & $11460 \pm 90$ & Ki-11136 & & & \\
\hline & $11250 \pm 150$ & $\mathrm{Ki}-8546$ & & & \\
\hline $\begin{array}{l}\text { Krynica } \\
\text { - Góra Parkowa }\end{array}$ & $12 \breve{Z ̆ 00} \pm 220$ & Gd-6095 & $\begin{array}{l}\text { bølling } \\
\text { Bølling }\end{array}$ & $\begin{array}{c}\text { Beski Sądecki } \\
\text { - dolna część osuwiska } \\
\text { Beskid Makowski- } \\
\text { lower part of landslide }\end{array}$ & Alexandrowicz (1996b) \\
\hline
\end{tabular}

Odrębnym zagadnieniem są etapy rozwoju osuwisk w holocenie, które były już rozpatrywane m.in. przez Alexandrowicza (1966b) i Margielewskiego (2006). Znaczną ich część wiąże się z okresami zwilgotnienia klimatu (Ralska-Jasiewiczowa, Starkel, 1988; Margielewski,
2006). W Karpatach, na podstawie oznaczeń ${ }^{14} \mathrm{C}$ i badań palinologicznych, wyróżniono kilka takich etapów aktywności osuwisk od początku holocenu (Alexandrowicz, 1996b; Margielewski, 2006). Znane są też pojedyncze osuwiska, które rozwijały się w czasie ostatnich lat, czego 
przykładem jest ponad 30-hektarowe osuwisko skalne w Kłodnym, które uruchomiło się w 2010 r.

Większość współcześnie zachodzących procesów osuwiskowych polega na odnawianiu starych, nieaktywnych osuwisk. Powstawanie nowych osuwisk wiąże się z najbardziej ekstremalnymi opadami, jakie ostatnio wystapiły na terenie Karpat np. w roku 1997, 2001 i 2010.

Przedstawione wyniki badań wskazują, że rozwój osuwisk może być bardzo długi - od późnego glacjału do czasów współczesnych. Wiąże się to z długotrwałym zagrożeniem terenów przez osuwiska, na co powinno się zwrócić uwagę przy planowaniu budynków i obiektów inżynierskich.

Autor składa serdeczne podziękowania Anonimowym Recenzentom za poświęcony czas oraz wszelkie uwagi merytoryczne, redakcyjne i wprowadzone bardzo trafne korekty w tekście, a także Redakcji Przegladu Geologicznego za porady oraz korekty w treści niniejszego artykułu.

\section{LITERATURA}

ALEXANDROWICZ S.W. 1990 - Zaporowe jeziorka osuwiskowe w Potoku Ścigockim koło Krościenka. Spraw. Pos. Kom. Nauk. PAN, 34: 1-2.

ALEXANDROWICZ S.W. 1993 - Late Quaternary Landslides at estern periphery of the National Park at Pieniny Mountains, Carpathians, Poland. Stud. Geol. Polon., 102: 209-225.

ALEXANDROWICZ S.W. 1996a - Malakofauna i wiek osuwiska pod Czajakową Skałą w Wąwozie Homole. Chroń. Przyr. Ojcz., 52 (4): 45-54. ALEXANDROWICZ S.W. 1996b - Holoceńskie fazy intensyfikacji procesów osuwiskowych w Krapatach. Kwart. AGH Geologia, 22 (3): 223-262.

GIL E., GILOT E., KOTARBA A., SZCZEPANEK K.,STARKEL L. 1974 An Early Holocene landslide in the Beskid Niski and its significance for paleographical reconstructions. Stud. Geomorph. Carparho-Balcan., 8: 69-83. GIL E., KOTARBA A. 1977 - Model of slide slope evolution in flysch mountains (An example drawn from the Polish Carpathians). Catena 4 (3): 233-248.

GIL E., KOTARBA A. 1979 - Model dynamicznego stoku osuwiskowego w obszarze fliszowym. Przykład z polskich Karpat. Zesz. Probl., Postęp. Nauk Roln., 222: 25-38.

GIL E., KOTARBA A. 1985 - Model of functioning of the landslide "Zapadle" in Szymbark. XIII Kongres KBGA, Przewodnik nr 5: 75-77. GOLONKA J., RĄCZKOWSKI W. 1984 - Szczegółowa mapa geologiczna Polski 1:50 000, ark. Piwniczna. Inst. Geol.

HACZEWSKI G., KUKULAK J. 2004 - Early Holocene landslide dammed lake in the Bieszczady Mountaiins (Polish East Carpathians) and its evolution. Studia Geomorph. Carpatho-Balcan., 38: 83-96.

KRĄPIEC M., DANEK M., GIL E., KŁUSEK M., RĄCZKOWSKI W. ZABUSKI L. 2008 - Monitoring dendrogeomorfologiczny osuwisk w Beskidzie Niskim. Pr. Kom. Paleogeogr. Czwart. PAU, 6: 173-184. KRĄPIEC M., MARGIELEWSKI W. 2000 - Analiza dendrogeomorfologiczna ruchów masowych na obszarze polskich Karpat fliszowych. Kwart. AGH Geologia, 26: 141-171.

LASKOWICZ I., WÓJCIK A. 2014 - Mapa osuwisk i terenów zagrożonych ruchami masowymi w skali 1 : 10 000, gm. Szczawnica, pow. nowotarski, woj. małopolskie; http://mapa.osuwiska.pgi.gov.pl MARGIELEWSKI W. 2001a - Rejestr zmian klimatycznych późnego glacjału i holocenu w obrębie torfowiska pod Kotoniem (Beskid Średni, Karpaty zewnętrzne). Prz. Geol., 49 (12): 1161-1166.

MARGIELEWSKI W. 2001b - Late Glacial and Holocene climatic changes registered in forms add deposits of the Klakowo Landslide (Beskid Średni Range, Outher Carpathians). Stud. Geomorph. Carpatho-Balcan., 35: 63-79.

MARGIELEWSKI W. 2006 - Records of the Late Glacial - Holocene paleoenviroonmental changes in landslide forms and deposits of the Beskid Makowski and Beskid Wyspowy Mts. Area (Polish Outer Carpathians). Folia Quatern., 76: 5-149.

MARGIELEWSKI W., OBIDOWICZ A., PELC S. 2003 - Late Glacial Holocene peat bog on Koton Mt. and its significance for reconstruction of paleoenviroonmental in the Western Outer Carpathians (Beskid Makowski Range, South Poland). Folia Quatern., 74: 35-56.

MARGIELEWSKI W., ZERNITSKAYA V. 2003 - Late Glacial - Holocene paleoenviroonmental evidenjce recorded in the Hajduki peat bog (Beskid Średni Mts., Outer Western Carpathians). Folia Quatern., 74: 57-73.
MANGERUND J., ANDESRSEN S.T., BERGLUNAD., DONNER J.J. 1974 - Quaternary stratigraphy of Norden, proposal for terminology and classification. Boreas, 3: 109-126.

NESCIERUK P., RĄCZKOWSKI W., WOJCIECHOWSKI T., WARMUZ B., KOWALSKI Z., DACKA J. 2014a - Dokumentacja geologiczna z prac monitoringowych wykonanych na osuwisku w m. Szymbark - Zapadle; http://mapa.osuwiska.pgi.gov.pl

NESCIERUK P., RACZKOWSKI W., WOJCIECHOWSKI T., WARMUZ B., MICHALSKI A., DACKA J. 2014b - Dokumentacja geologiczna $\mathrm{z}$ prac monitoringowych wykonanych na osuwisku $\mathrm{W} \mathrm{m}$. Rychwałd; http://mapa.osuwiska.pgi.gov.pl

PÁNEK T. 2015 - Recent progress in landslide dating: A global overview. Prog. Phys. Geogr., 39: 168-198; doi:10.1177/0309133314550671

PÁNEK T., ENGEL Z., MENTLÍK P., BRAUCHER R., BŘEŽNÝ M., ŠKARPICH V., ZONDERVAN A. 2016 - Cosmogenic age constraints on post-LGM catastrophic rock slope failures in the Tatra Mountains (Western Carpathians). Catena, 138: 52-67; doi:10.1016/j.catena.2015.11.005

PÁNEK T., HARTVICH F., JANKOVSKÁ V., KLIMEŠ J., TÁBOŘÍK P., BUBÍK M., SMOLKOVÁ V., HRADECKÝ J. 2014 - Large Late Pleistocene landslides from the marginal slope of the Flysch Carpathians. Landslides, 11: 981-992; doi:10.1007/s10346-013-0463-8

PÁNEK T., MENTLÍK P., ENGEL Z., BRAUCHER R., ZONDERVAN A. 2017 - Late Quaternary sackungen in the highest mountains of the Carpathians. Quat. Sci. Rev., 159: 47-62; doi:10.1016/j.quascirev.2017.01.008 PAWLIKOWA B. 1965 - Materials for the postglacial history of vegetation of the West Carpathians, peat bog on the Bryjarka. Folia Quatern., 18: $1-9$.

PAZDUR A., GOSLAR T., MICHCZYŃSKI A., PAWLYTA J. 1999 Zastosowanie metody radiowęglowej do datowania osadów młodszego czwartorzędu. [W:] Geochronologia górnego czwartorzędu Polski w świetle datowania radiowęglowego i liuminescencyjnego. Inst. Fizyki Pol. Śl.: 17-42.

POPORAWA D., RĄCZKOWSKI W. 2003 - Osuwiska Karpat. Prz. Geol., 51 (8): 685-692.

RALSKA-JASIEWICZOWA M., STARKEL L. 1988 - Record of the hydrological changes during the Holocene in the lake, mire and fluvial deposits of Poland. Folia Quatern., 57: 91-127.

RACCZKOWSKI W., MROZEK T. 2002 - Activating of landsliding in the Polish Flysch Carpathian by the end of the $20^{\text {th }}$ century. Stud. Geomorph. Carpatho-Balcan., 36: 91-111.

RYŁKO W., PAUL Z. 2014 - Szczegółowa Mapa Geologiczna Polski w skali 1:50 000, ark. Lachowice (1013). Państw. Inst. Geol.

STARKEL L. 1984 - Karpaty i kotliny podkarpackie, zlodowacenia północnopolskie. [W:] Budowa Geologiczna Polski, t. 1, Stratygrafia, cz. 3.1, Kenozoik Czwartorzęd. Inst. Geol.: 297-308.

SOBOLEWSKA M., STARKEL L., ŚRODOŃ A. 1964 - Młodoplejstoceńskie osady z flora kopalną w Wadowicach. Folia Quatern., 16: 1-64. SZCZEPANEK K. 2001 - Late Holocene vegetation history in the Dukla Pass region (Low Beskidy, Carpathians) based on pollen and macrofossil analyses. Acta Paleobot., 41 (2): 341-353.

SZCZYGIEŁ J., MENDECKI M., HERCMAN H., WRÓBLEWSKI W., GLAZER M. 2019 - Relict landslide development as inferred from speleothem deformation, tectonic data and geoelectrics. Geomorphology, 330: 116-128; doi:10.1016/j.geomorph.2019.01.017

ŠILHÁN K., PÁNEK T., DUŠEK R., HAVLŮ D., BRÁZDIL R., KOŠIČKOVÁ J., HRADECKÝ J. 2013 - The dating of bedrok landslide reativations using dendrogeomorphic techniques: The Mazak landslide, Outer Western Carpathians (Czech Republic). Catena, 104: 1-13.

ŚRODOŃ A. 1952 - Późnoglacjalna flora z Dziadowych Kątów koło Grywałdu. Biul. Państw. Inst. Geol., 67: 77-97.

URBAN J., MARGIELEWSKI W., HERCMAN H., ŽÁK K. ZERNITSKA V., PAWLAK J., SCHEJBAL-CHWASTEK M. 2015 Dating of speleothems in non-karst caves - methodological aspects and practical application, Polish Outer Carpathians case study. Zeitschr. Geomorph., 59: 185-210; doi:10.1127/zfg

WIECZOREK D. 2009 - Mapa osuwisk i terenów zagrożonych ruchami masowymi w skali 1 : 10 000, gm. Gilowice, pow. żywiecki, woj. śląskie. Państw. Inst. Geol.; http://mapa.osuwiska.pgi.gov.pl

WOJCIECHOWSKI T, BORKOWSKI A., PERSKI Z., WÓJCIK A. 2012 - Dane z lotniczego skaningu laserowego w badaniu osuwisk przykład osuwiska w Zbyszycach (Karpaty zewnętrzne). Prz. Geol., 60 (2): 95-102.

WÓJCIK A. 1958 - Osuwiska ziemi w Beskidzie Niskim i Bieszczadach. Wierchy, 27: 189-194.

WÓJCIK A. 1997 - Osuwiska w dorzeczu Koszarawy - uwarunkowania strukturalne i geologiczne. Biul. Państw. Inst. Geol., 376: 5-42.

WÓJCIK A., MROZEK T., GRANOSZEWSKI W. 2006 - Litological conditioning of Landslides and Climatic Changes with exemples from the Beskid Mts., Western Carpathians, Poland. Geogr. Fis. Dinam. Quat., 29: 197-209. 